\title{
THE LEVEL OF TEACHERS UNDERSTANDING IN PHYSICAL EDUCATION, SPORTS AND HEALTH ABOUT THE 2013 CURRICULUM
}

\begin{tabular}{l} 
Aprizal Fikri ${ }^{1}$, Bayu Hard \\
${ }^{12}$ Universitas Bina Darma, \\
\hline Article Info \\
\hline Article History: \\
Received September 2020 \\
Revised September 2020 \\
Accepted September 2020 \\
Available online September 2020 \\
-_ \\
Keywords: \\
syllabus, lesson plans, \\
learning methods, 2013 \\
curriculum
\end{tabular}

Aprizal Fikri ${ }^{1}$, Bayu Hardiyono ${ }^{2}$

${ }^{12}$ Universitas Bina Darma, Indonesia

\begin{abstract}
This study aims to determine the level of understanding of teachers in physical education, sports, and health in Line 20 Muara Padang District about K13 Learning. The research method used in this research is descriptive quantitative. The sample in this study were junior high schools in Line 20, Muara Padang district, Banyuasin district with a total of 20 teachers. This study uses 3 indicators, namely understanding the PJOK learning syllabus in the 2013 curriculum, understanding the principles of RPP preparation in learning PJOK in the 2013 curriculum, and understanding the methods of learning PJOK in the 2013 curriculum. The results showed that at the junior high school level understanding the PJOK learning syllabus in the curriculum 2013 got an average value of 54.2 of $55 . \%$ and was included in the high category.
\end{abstract}

Corresponding address: Jl. Jenderal Ahmad Yani No.3, 9/10 Ulu, Kecamatan
Seberang Ulu I, Kota Palembang, Sumatera Selatan
Email
:aprizal.fikri10@binadarma.ac.id

Email
ISSN 2685-6514 (online)

ISSN 2477-331X (print)

DOI : 10.33369/jk.v4i2.12500 


\section{INTRODUCTION}

As time goes by and with the increasing intellectual level and quality of life, the dimensions of education are becoming increasingly complex, and of course this requires an educational design that is also appropriate and in accordance with the conditions. Therefore, various theories, methods, and educational designs were created and created to appreciate the increasingly diverse levels of needs and complexity of educational problems (Taufik Rizaldi 2015). "In the development of educational theory and design, it has an impact on a system that will be applied in an educational application that was agreed upon at that time, namely the curriculum, a theory that provides views on education, so that innovation and creativity of theorists emerge to give birth to more theories. contextual, which will also stimulate the creation of a new educational design that will apply these theories in a system. Educational theory is the foundation in the development of educational practices, for example curriculum development, teaching and learning processes and school management. A curriculum and learning plan are prepared with reference to educational theory "(Kadir., Et al, 2012).

"Education is the main thing that can sustain the progress of a nation. Without education, a country will be far behind other countries". "Education occupies a central position in development because the goal is to improve the quality of human resources, development in relation to human resource development, which means that development is not merely material and physical development but spiritual development, namely human development which is the main task of education" (yuliani : 2016). Traditionally, schools around the world have emphasized academic achievement, driven by the imperative to prepare children for the job market (OECD: 2019).

When measured from the quality
and existing education system, educational institutions carry the mandate to prepare their students to be able to survive and have character (Tilaar, 2012). "Based on a survey conducted by Political and Economic Risk Consultants (PERC) in 2012, it shows that the quality of education in Indonesia is ranked 12th out of 12 countries in Asia", the results of this survey are quite alarming. Meanwhile, a survey conducted by "The World Economic Forum Sweden (2000) shows that Indonesia has very low competitiveness. It only ranks 37 th out of 57 countries included in this survey ". (Sujarwo, 2013). "In general, there are four main problems in national education that need to be prioritized overcoming them (Ujiyanti, Tatak Prapti; 2009). The problems in question are; 1) The problem of equal opportunity and access to education; 2) Quality improvement problems; 3) Issues of educational relevance; and 4) Efficiency problems and the education management system ". 
This situation is very irrelevant with the purpose of "Law number 20 of 2003 concerning the National education system. Where in article 3 states that the creation of the National Education System is to form a dignified character and civilization of the nation in order to educate the nation's life. One way is to develop the potential of students to become human beings who believe and obey God Almighty, have noble character, are healthy, knowledgeable, capable, creative, independent and become democratic and responsible citizens ". "This education system is also expected to be able to prepare the Indonesian nation to face challenges in the future, as stated by Huntington" (Nuh, 2013). To create the desired state, "It is necessary to have the suitability of each supporting component to achieve the educational goals itself, one of which is the curriculum". The curriculum is used to describe a set plan, a complete set of experiences, or content that is measured from an experience; as a single class session, a group of classes, or a defined learning period (Jinhong Jung1, James Ressler2, Amy Linder1, 2018). In addition, the curriculum must be able to make the current generation think creatively and innovatively, have character, love the country and are proud to be the Indonesian nation. or the specified learning period (Jinhong Jung1, James Ressler2, Amy Linder1, 2018). In addition, the curriculum must be able to make the current generation think creatively and innovatively, have character, love the country and are proud to be the Indonesian nation. or the specified learning period (Jinhong Jung1, James Ressler2, Amy Linder1, 2018). In addition, the curriculum must be able to make the current generation think creatively and innovatively, have character, love the country and are proud to be the Indonesian nation.

The education system in Indonesia has undergone several changes in the curriculum. Starting from the preindependence period curriculum to the latest 2013 curriculum. Changes in this curriculum have in fact affected the standards and components of education. "The curriculum must always be updated in line with changes in order to remain relevant to changes in society" (Prihantoro 2014). Especially in the 2013 curriculum, auntentic assessment becomes a serious emphasis when the teacher assesses student learning outcomes. For example, by adding competencies outside the learning material. K-13 is designed to prepare Indonesian people to have the ability to live as individuals and citizens who believe, be productive, creative, innovative, and affective, and are able to contribute to social life.

The implementation of K-13 begins with designating certain schools as pilot schools which are known as piloting schools. Initially, the curriculum targets were grade I and grade IV Elementary School (SD) / Madrasah Ibtidaiyah (MI), grade VII Junior High School (SMP) / Madrasah Tsanawiyah (MTs), and class $\mathrm{X}$ Senior High School (SMA) / 
Vocational High School. (SMK) / Madrasah Aliyah (MA) academic year 2013/2014. Preparation for implementation begins with providing training for teachers in the class which is followed by mentoring activities as an effort to make K-13 run well.

Physical competence is clearly one of the elements of learning (Andrew Sprake1 and Claire Temple2, 2016) In PJOK subjects which are included in the "2013 curriculum, namely a group of subjects whose content is developed by the central government and equipped with local wisdom content developed by local governments, Its application can be integrated with the basic competencies that are already included in the curriculum, or can add its own basic competencies. In the curriculum structure of PJOK subjects, the allocation of time is 3 lesson hours each week, where the allocation of learning hours for each class is the minimum amount that can be added according to the needs of students. The structure of the 2013 Curriculum, PJOK subjects have content that contributes to developing competency in movement and a healthy lifestyle, and give color to the character education of the nation ". "Learning PJOK with local wisdom will give appreciation to multiculturalism, namely getting to know traditional games and sports which are rooted in Indonesian ethnic culture and can contribute to character building". The same thing was also conveyed by (Cronin, Allen, Mulvenna \& Russel 2018) that physical education is a subject that can improve the development of life skills and psychological well-being of students.

In an article written by Ikak Krisdianto (2017), "Based on the results of this study it shows that the level of understanding of PJOK teachers towards the implementation of the 2013 revised curriculum in SMP, SMA and Equivalents in Dawarblandong District for monitoring and evaluation questionnaires gets a percentage of $75.43 \%$ and for Observations of PJOK teachers have a percentage of $73.75 \%$ which is then corrected into the "high" category value. So the PJOK teachers in SMP, SMA and Equivalents in Dawarblandong Mojokerto Subdistrict for the level of understanding of the 2013 revised curriculum get the "high" category. Likewise when we refer to the article written by Moch. Arief Sultoni, (2015) "the implementation of the 2013 curriculum for PJOK subjects at SMP level at One Roof Schools on Gili Ketapang Island and target schools in Probolinggo Regency has been implemented, but not completely run well. This can be seen through the results of the research which shows that the percentage for One Roof Junior Secondary School on Gili Ketapang Island is $72.38 \%$, while the target One Roof School in Probolinggo Regency is $74.39 \%$ and both are in the sufficient category".

Muara Padang is a sub-district in the district. Banyuasin, South Sumatra, Indonesia. Muara Padang sub-district consists of fifteen villages, namely 
"Karang Newar, Tanjung Baru, Muara Padang, Margomulyo, Purwodadi, Sumber Makmur, Sidomulyo, Ivory Water, Tirtoraharjo, Tirtajaya, Sidorejo, Margo Sugihan, Sidomulyo, Daya Maakmur, Main Power". Based on the observations of researchers in the estuary of Padang, to be precise, on line 20, the 2013 curriculum program has been implemented. This was expressed by several teachers through interviews conducted by the author. So that there is a new curriculum, not all PJOK teachers follow the training that is implemented so that the understanding of each teacher is different. In addition, various problems that hinder the education process in an area still often arise. There is still a lack of facilities and infrastructure. "There are no sufficient facilities to support the progress of the teaching and learning process they are doing, as well as students who teach with minimal knowledge. This happens a lot in Indonesia, especially in the border areas in Indonesia and one of them is in the area of Line 20, Muara Padang District, South Sumatra "

Based on the literacy study conducted by the researcher, the core of this research is the level of understanding of the PJOK eye teacher, namely understanding the PJOK learning syllabus in the 2013 curriculum, understanding the principles of preparing RPP in learning PJOK in the 2013 curriculum, and understanding the methods of learning PJOK in the 2013 curriculum.

\section{METHOD}

The research method used in this research is non-experimental research with a quantitative approach. According to Maksum (2012), "the type of nonexperimental research is where the author does not have the opportunity to provide treatment or manipulate variables that may play a role in the appearance of a symptom". "Because the observed symptoms have occurred. The design used in this study was a survey. Where is the research design that takes a sample from a population and uses a questionnaire as a primary data collection tool and bases itself on deductive logic ". "According to Maksum (2012), deductive logic begins with using theory as a basis and ends with analysis of measurement results."

The population in this study were 20 primary school PJOK teachers, namely: MTS AL-Muhajirin Muara Padang, MTS Assanudiyah, MTS Darul Abroor, MTS Raudhatul Ulum, MTS 1 Muhamadiyah Muara Padang, Santo Louis Junior High School, Tunas Bangsa Muara Padang Middle School, SMP N 1 Muara Padang, SMP N 2 Muara Padang. Sampling in this study was carried out by taking all data from a population of 20 people.

The instrument used in this study was a questionnaire in the form of a questionnaire. Questionnaire containing positive and negative statements that aim to compare the consistency of answers. As a means of collecting data, this 
questionnaire is presented in a closed form so that respondents simply choose the answers provided. The score used in this study uses a Likert scale which has five alternative answers, namely: strongly agree / often, agree / often, doubt / sometimes, disagree / rarely, and strongly disagree / never. Alternative answers to doubt are removed so that the answer is more optimal. So that there are four alternative answers provided. The scoring of each answer is as follows:

Table 1. Likert scale

\begin{tabular}{lccc}
\hline \multicolumn{1}{c}{ Answer } & Code & $\begin{array}{c}\text { Positive } \\
\text { Score }\end{array}$ & Score \\
\hline $\begin{array}{l}\text { Strongly } \\
\text { agree }\end{array}$ & SS & 4 & 1 \\
Agree & S & 3 & 2 \\
Disagree & TS & 2 & 3 \\
Strongly & STS & 1 & 4 \\
Disagree & & & \\
\hline
\end{tabular}

The following instrument grid is presented. To find out in more depth how far teachers understand the research curriculum with criteria based on Permendikbud Number 20 of 2016 concerning Competency Standards for Primary and Secondary Education Graduates, "Permendikbud Number 21 of 2016 Regarding Content Standards for Primary and Secondary Education, Number 22 of 2016 concerning Basic and Secondary Education Process Standards, Permendikbud Number 23 of 2016 concerning Educational Assessment Standards, and Permendikbud Number 24 of 2016 concerning Core Competencies and Basic Competencies of Lessons in the 2013 Curriculum in Primary and Secondary Education ".
The initial process of data analysis is descriptive data. The data taken is the result of data from filling out the questionnaire by the Physical Education teacher. Data collection aims to strengthen the statements filled by respondents. The author organizes the data, describes it into units, "describes the results of collecting survey instruments which are the results of research subjects. The data analysis technique used is descriptive quantitative, with the following formula":

$$
\begin{aligned}
& \text { persentase } \\
& =\frac{\text { jumlah skor }}{\text { jumlah skor terting i }} \times 100 \% \\
& \text { "For the scale of assessment, }
\end{aligned}
$$
researchers use the Likert scale, which is the method of scaling that uses the distribution of responses to understand very well as the basis for determining the value, (Maksum, 2012). The distribution of answers is on a psychological continuum ranging from 1 - 4 ".

$1=$ don't understand

$2=$ Don't understand

$3=$ Got it

$4=$ Very Understanding

The data of this study consisted of data on the level of understanding of teachers in PJOK subjects in junior high schools. The level of understanding of the PJOK subject teachers, namely understanding the PJOK learning syllabus in the 2013 curriculum, understanding the principles of preparing RPP in PJOK learning in the 2013 curriculum, and understanding the methods of learning PJOK in the 2013 
curriculum.In this study using a questionnaire with a total of 36 questions by understanding the learning syllabus PJOK in the 2013 curriculum consists of 14 questions, understanding the principles of preparing RPP in learning PJOK in the 2013 curriculum, amounting to 11 questions, and understanding the methods in learning PJOK in the 2013 curriculum totaling 11 questions that have been validated by 3 experts.

a. Understanding the PJOK Learning Syllabus in the 2013 Curriculum for Junior High School Levels

Indicators of understanding the PJOK learning syllabus in the 2013 curriculum for junior high school level with a questionnaire totaling 20 teachers with a score of 1 to 4. Data obtained from Indicators of understanding the PJOK learning syllabus in the 2013 curriculum for junior high school levelobtained the lowest score (minimum) 52, the highest score (maximum) 56, the average (mean) 54.2. The data that has been obtained are then converted into four categories, the following results are obtained:

Table 2.Percentage Understanding of PJOK Learning Syllabus in the 2013 Curriculum at the First Middle School Level

\begin{tabular}{|c|c|c|c|c|}
\hline $\begin{array}{l}\mathrm{N} \\
\mathrm{o} .\end{array}$ & Range & $\begin{array}{l}\text { Categ } \\
\text { ory }\end{array}$ & $\begin{array}{l}\text { Freque } \\
\text { ncy }\end{array}$ & $\begin{array}{l}\text { Percent } \\
\text { age }\end{array}$ \\
\hline 1 & $\begin{array}{l}55<\mathrm{X} \leq \\
56\end{array}$ & $\begin{array}{l}\text { Very } \\
\text { high }\end{array}$ & 2 & $10 \%$ \\
\hline 2 & $\begin{array}{l}54<X \leq \\
55\end{array}$ & High & 11 & $55 \%$ \\
\hline 3 & $\begin{array}{l}53<\mathrm{X} \leq \\
54\end{array}$ & Low & 5 & $25 \%$ \\
\hline 4 & $\begin{array}{l}52<\mathrm{X} \leq \\
53\end{array}$ & $\begin{array}{l}\text { Very } \\
\text { low }\end{array}$ & 2 & $10 \%$ \\
\hline \multicolumn{3}{|c|}{ total } & 20 & $100 \%$ \\
\hline
\end{tabular}

Based on the table above, it shows that understanding the PJOK learning syllabus in the 2013 curriculum at the First Menangah School level in the Muara Padang district, Banyuasin district based on an understanding of the PJOK learning syllabus in the 2013 curriculum at the junior high school level is in the "very high" category of $10 \%$ (2 teachers), "High" is $55 \%$ (11 teachers), "low" is $25 \%$ (5 teachers), and "very low" is $10 \%$ (teachers). Based on the average value, which is the average (mean) 54.2, understanding the PJOK learning syllabus In the 2013 curriculum at the junior high school level in Muara Telang sub-district, Banyuasin district is in the "high" category

The following is presented in the form of a histogram to make it easier to understand the table:

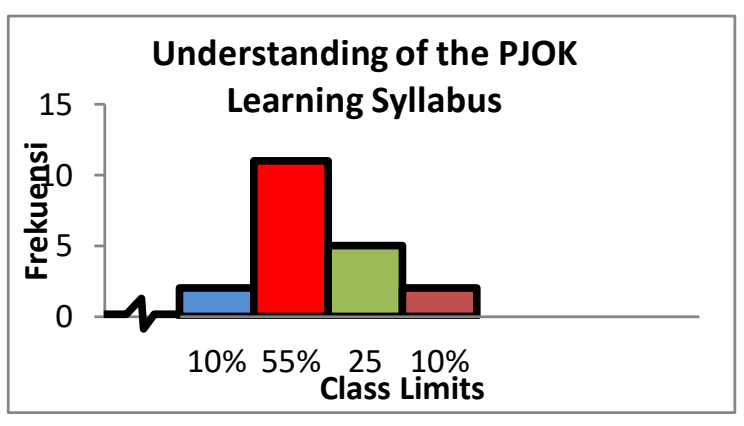

The histographical understanding of the PJOK learning syllabus in the 2013 curriculum at the First Menangah School level

b. Understand the Principles of RPP Preparation in PJOK Learning in the 2013 Curriculum for Junior High School Level

The indicator understands the principles of preparing RPP in PJOK learning in the 2013 curriculum at the 
junior high school level with a questionnaire totaling 20 teachers with a score of 1 to 4. Data obtained from indicators understand the principles of preparing RPP in PJOK learning in the 2013 curriculum at the junior high school levelobtained the lowest score (minimum) 40, the highest score (maximum) 44, mean (mean) 43.2. The data that has been obtained are then converted into four categories, the following results are obtained:

Table 3 Percentagesunderstanding the Principles of RPP Preparation in PJOK Learning in the 2013 Curriculum for Junior High School Level

\begin{tabular}{ccccc}
\hline $\begin{array}{l}\mathrm{N} \\
\text { o. }\end{array}$ & Range & $\begin{array}{l}\text { Categ } \\
\text { ory }\end{array}$ & $\begin{array}{l}\text { Frequ } \\
\text { ency }\end{array}$ & $\begin{array}{l}\text { Percen } \\
\text { tage }\end{array}$ \\
\hline 1 & $\begin{array}{l}43<\mathrm{X} \\
\leq 44\end{array}$ & $\begin{array}{l}\text { Very } \\
\text { high }\end{array}$ & 3 & $15 \%$ \\
2 & $\begin{array}{l}42<\mathrm{X} \\
\leq 43\end{array}$ & High & 8 & $40 \%$ \\
3 & $\begin{array}{l}41<\mathrm{X} \\
\leq 42\end{array}$ & Low & 6 & $30 \%$ \\
4 & $\begin{array}{l}40<\mathrm{X} \\
\leq 41\end{array}$ & $\begin{array}{l}\text { Very } \\
\text { low }\end{array}$ & 3 & $15 \%$ \\
\multicolumn{1}{l}{ total } & & 20 & $100 \%$ \\
\hline
\end{tabular}

Based on the table above, it shows that the indicators understand the principles of RPP preparation in PJOK learning in the 2013 Junior High School level curriculum in Muara Padang subdistrict, Banyuasin district based on an understanding of the PJOK Learning Syllabus in the 2013 Junior High School level curriculum in the "very high" category of $15 \%$ ( 3 teachers), "high" was $40 \%$ (8 teachers), "low" was 30\% (6 teachers), and "very low" was $15 \%$ (3 teachers). Based on the average value of 43.1, Understanding the principles of preparing RPP in PJOK learning in the 2013 curriculum at the junior high school level in Muara padang sub-district, Banyuasin district, is in the "High" category.

The following is presented in the form of a histogram to make it easier to understand the table:

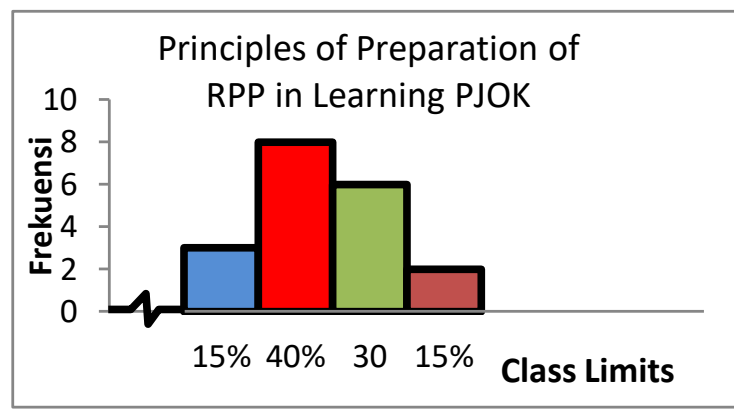

Histographical understanding of the Principles of RPP Preparation in the 2013 curriculum at the junior high school level

c. Understanding the Methods in Learning PJOK in the 2013 Curriculum for Junior High School Level

Indicators of Understanding Methods in Learning PJOK in the 2013 curriculum at the elementary school level with a questionnaire totaling 34 teachers with a score of 1 to 4 . The data obtained from the indicators of understanding methods in learning PJOK in the 2013 curriculum at the junior high school level obtained the lowest score (minimum) of 40 highest (maximum) 44, mean (mean) 43.1. The data that has been obtained are then converted into four categories, the following results are obtained:

Table 4 Percentage of Understanding Methods in Learning PJOK in the 2013 Curriculum for Junior High School Level

\begin{tabular}{lllcc}
\hline $\mathrm{N}$ & Range & $\begin{array}{l}\text { Categ } \\
\text { ory }\end{array}$ & $\begin{array}{l}\text { Frequ } \\
\text { ency }\end{array}$ & $\begin{array}{l}\text { Percen } \\
\text { tage }\end{array}$ \\
\hline 1 & $\begin{array}{l}43<\mathrm{X} \\
\leq 44\end{array}$ & $\begin{array}{l}\text { Very } \\
\text { high }\end{array}$ & 5 & $25 \%$ \\
2 & $\begin{array}{l}42<\mathrm{X} \\
\leq 43\end{array}$ & High & 12 & $60 \%$ \\
& & & \\
\hline
\end{tabular}




\begin{tabular}{cllll}
\hline 3 & $\begin{array}{l}41<\mathrm{X} \\
\\
\leq 42\end{array}$ & Low & 1 & $5 \%$ \\
4 & $\begin{array}{l}40<\mathrm{X} \\
\leq 41\end{array}$ & $\begin{array}{l}\text { Very } \\
\text { low }\end{array}$ & 2 & $10 \%$ \\
\multicolumn{2}{c|}{ total } & & 20 & $100 \%$ \\
\hline
\end{tabular}

Based on the table above, it shows that the indicators of understanding the method in learning PJOK in the 2013 curriculum at the junior high school level in Muara Padang sub-district, Banyuasin district based on an understanding of the methods in learning PJOK in the 2013 curriculum at the junior high school level are in the "very high" category of $25 \%$ (5 teachers), "high" was 60\% (12 teachers), "low" was 5\% (1 teacher), and "very low" was $10 \%$ (2 teachers). Based on the average value of 43.04, understanding the method of learning PJOK in the 2013 curriculum at the junior high school level in the Muara padang sub-district, Banyuasin district is in the "high" category.

The following is presented in the form of a histogram to make it easier to understand the table:

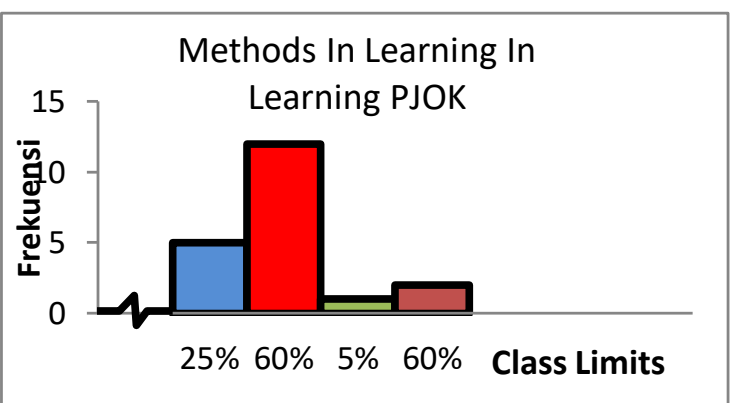

Histographical understanding of the method in learning in the 2013 curriculum at the junior high school level

\section{DISCUSSION}

This study aims to determine how high the level of understanding of PJOK subject teachers in Muara Padang District about the 2013 curriculum learning. "The study was conducted using an instrument in the form of a research questionnaire. The data analysis technique used is descriptive analysis with the calculation using the percentage "

Based on the research results show that the level of understanding of PJOK teachers in understanding the learning syllabus of PJOK in the 2013 curriculum gets an average score of 54.2 with a percentage of $55 \%$ and is in the high category, then for the level of understanding of PJOK teachers in understanding the principles of preparing lesson plans in learning PJOK in the 2013 curriculum got an average value of 43.2 with a percentage of $40 \%$ and was included in the high category, then the level of understanding of PJOK teachers in understanding the methods of learning PJOK in the 2013 curriculum got an average value of 43.04 with a percentage of $60 \%$ and falls into the high category.

The implementation of the 2013 curriculum in Muara Padang District has been considered good, from the results of observations made by teacher researchers in Muara Padang District starting by designing a learning planning program design in the form of a syllabus and a learning implementation plan which describes the core competencies and basic competencies that have been determined National Education Standards Agency. The roles and responsibilities of teachers in developing the syllabus are analyzing competency designs and competency indicators as well as standard materials, compiling lesson plans, developing learning strategies and developing learning media and methods.

Based on the results of interviews and document studies, "that the curriculum document is in the form of a syllabus made by the teacher in accordance with the format and 
procedures in syllabus development. The format of the syllabus is still based on the curriculum at the educational unit level, which includes at least competency standards, basic competencies, indicators, standard materials, standards for teaching and learning activities and assessment standards The procedure in developing a syllabus in outline includes filling in the identity column, reviewing and analyzing competency standards and basic competencies, identifying standard material, developing learning experiences, formulating indicators, determining types of assessment, allocating time and learning resources, while the syllabus model developed by teachers in schools can be modified, adapted to the characteristics of students, the situation and condition of schools and regions by still referring to competency standards and basic competencies ". Based on the data in the field, it is revealed that, in making the planning program for the Elementary School Mimbar, learning there are several things that need to be considered by the teacher, namely learning objectives (competency standards and basic competencies), learning materials, media and learning methods, student learning experiences and formulating indicators.

Teachers' understanding of the 2013 curriculum is also supported by school programs and government programs through the Subject Teacher Conference (MGMP) activities, especially teachers of Physical Education, Sports and Health (PJOK) in their respective schools, 2013 curriculum development workshops, and other activities. . With this program, it aims to make teachers understand the structure and framework of the 2013 curriculum learning unit curriculum, and its application in learning activities in the classroom.
In addition, it can also be supported by the teachers filling in the questions in the questionnaire given, so that they can answer questions very well about understanding the PJOK learning syllabus in the 2013 curriculum, understanding the principles of preparing RPP in learning PJOK in the 2013 curriculum, and understanding the methods of learning PJOK in the 2013 curriculum. curriculum 2013. Of all the teachers were able to answer the questionnaire given in the high category.

Based on the results of the research and discussion that has been described, it can be concluded that: At the junior high school level, understanding the PJOK learning syllabus in the 2013 curriculum gets an average value of 54.2 of 55.\% and is included in the high category, to understand the principles of RPP preparation in learning PJOK in the 2013 curriculum gets an average value of 43.2 by $40 \%$ and is in the high category, and understanding the method of learning PJOK in the 2013 curriculum gets an average value of 43.1 by $60 \%$ and is in the high category.

\section{SUGGESTION}

From the above conclusions, there are suggestions that can be used as a reference and evaluation for all junior high schools "especially in the fields of physical education, sports and health, namely; For the next research, this research is still in the scope of "Junior High School," it is hoped that the next researcher will expand the scope of the research so that the data obtained is more perfect and ensures the conformity between the respondent's answer with the actual situation such as overseeing the filling of the questionnaire from every aspect and observing the learning process. . Furthermore, for teachers who are still in the lack of 
understanding category, it is hoped that they will learn more and improve their understanding and implementation of the 2013 curriculum so that they can meet the demands of the times.

\section{REFERENCE}

Arief Sultoni, Moch. (2015). Implementation of 2013 Curriculum Subject at Junior High School Level Corner in One Roof Schools on Gili Ketapang Island and Probolinggo Regency. Journal of Sports and Health Education Volume 03 Number 02 Year 2015, 243 - 248

Cronin, LD., Allen, J., Mulvenna, C \& Russell, P (2017). An investigation of the relationships between the teaching climate, students' perceived life skills development and well-being within physical education. Physical Education and Sport Pedagogy. 23 (2). https://doi.org/10.1080/17408989.201 7.1371684

Krisdianto Ikak (2017), Survey of Pjok Teacher's Level of Understanding Against the Implementation of 2013 Curriculum Revision of Pjok Subjects in Junior High Schools, Senior High Schools in Dawarblandong Mojokerto District in 2017. Journal of Sports and Health Education Volume 05 Number 03 of 2017, 595 - 599

Jung, Jinhong, .Ressler, James ,. Linder, Amy. (2018). Exploring the Hidden Curriculum in Physical Education. Advances in Physical Education. 8 (2). 253-262. DOI: 10.4236 / ape. 2018.82023

Kadir Abdul, et al. 2012.Basics of Education. Jakarta: Kencana Prenada, Media Group.

Absolutely, Ali. 2012. Research Methodology in Sports. Surabaya: Unesa University Press.
Mendikbud. 2014. Teacher Training Materials for the Implementation of 2013 Curriculum for the 2014/2015 academic year, PJOK SMP / MTs for Teachers, Center for Educator Professional Development. Education and Culture Human Resources Development Agency and Education Quality Assurance, Ministry of Education and Culture.

Noah, Mohammad. 2013. Sowing Civilization Creators. Jakarta: Zaman.

OECD. (2019). Making Physical Education Dynamic and Inclusive for 2030: International Curriculum Analysis. Paris. Center français d'exploitation du droit de copie.

Political and Economic Risk Consultant (PERC) Score of Good Corporate Governance in Asian Countries in 2012 (www.asiarisk.com).

Prihantoro, C. Rudy. (2015). The perspective of the curriculum in Indonesia on environmental education. International Journal of Research Studies in Education. Volume 4 Number 1, 77-83 Rizaldi, Taufik. (2015). Theory of Education Related to the Curriculum. (On line). Downloaded from http://taufikrizaldi.blogs.uny.ac.id/201 5/11/04/teori-pend Pendidikan-yangberhubungan-dengan-kurriculum/ [access date November 4, 2015]

Sprake, A. and Temple, C. (2016) Physical Education or Physical Entertainment: where's the education in PE? Journal of Qualitative Research in Sports Studies, $10,1,157-176$

Sugiyono. 2010. Quantitative Research Methods, Qualitative, and R \& D. Bandung: Alfabeta

Sujarwo. (2013). Education in Indonesia is poor. WUNY Scientific Journal. XV, 1. 
Tilaar, HAR 2012. Kaleidoscope of National Education. Jakarta: Gramedia.

Law No. 20 of 2003 on the National Education System. Jakarta: Depdiknas (2003).

Ujiyanti, Tatak Prapti. 2009. Basic Education Reform in Indonesia. Policy Assessment, The Indonesian Institute Yuliani, (2016). Education in Indonesia in the Human Development Index (HDI). PPKn Scientific Rontal Journal, Volume 2, No. 2 